\title{
Effects of Chromium Propionate on Response to an Intravenous Glucose Tolerance Test in Growing Holstein Heifers ${ }^{1}$
}

\author{
J. M. Sumner, ${ }^{\star}$ F. Valdez, $\dagger$ and J. P. McNamara*2 \\ *Department of Animal Sciences, Washington State University, Pullman 99164-6351 \\ †Kemin Agri Foods North America, Inc., Des Moines, IA 50301
}

\begin{abstract}
To test the effect of chromium propionate on glucose utilization in growing dairy heifers, $0,5,10$, or $15 \mathrm{mg}$ of chromium/d were fed to 20 Holstein heifers of 11 to 14 mo of age, in a replicated Latin square. A 2-wk adaptation period was followed by 4 periods of 2 wk each with a 2-wk flush out period between treatments. Treatments were allotted to periods in a design balanced for potential carryover effects. Chromium propionate was fed in 0.25 $\mathrm{kg} / \mathrm{d}$ of ground corn individually. After $14 \mathrm{~d}$ on each treatment, animals were fitted with an indwelling jugular catheter, and an intravenous glucose tolerance test was conducted the following morning. Body weights increased throughout the experiment, but weights and condition scores were unaffected by treatment. Chromium supplementation increased basal glucose and decreased basal insulin and nonesterified fatty acids (NEFA) in serum in a dose-dependent, quadratic manner. Chromium increased glucose clearance rate as measured by half-life, time to nadir, and area under the curve. Over all periods, insulin concentrations tended to be lower in treated animals whereas clearance rates were unchanged. Serum NEFA levels were negatively correlated with glucose, such that treated animals with increased glucose had lower NEFA overall. There was an apparent long-term effect of chromium, because heifers in period 4 on the control diet had reduced insulin concentrations than those in the other control periods. Chromium propionate may increase glucose utilization in growing dairy heifers.
\end{abstract}

Key words: chromium, glucose tolerance, heifer, insulin

\section{INTRODUCTION}

Chromium in the +3 state is a trace mineral recognized as required for optimal insulin action and uptake of glu-

\footnotetext{
Received September 25, 2006.

Accepted February 14, 2007.

${ }^{1}$ This paper published with partial support from Kemin Agri Foods North America, Inc., Des Moines, Iowa, and the Agricultural Research Center, Washington State University. This paper published in conjunction with the NC-1009 CREES Regional Research Project "Protein Synthesis in Lactating Dairy Cattle."

${ }^{2}$ Corresponding author: mcnamara@wsu.edu
}

cose in insulin-sensitive organs (Anderson, 1987; NRC, 1997). Deficiency signs include insulin resistance and impaired glucose tolerance. Chromium is involved in autoamplification of insulin signaling to maintain the insulin receptor in the active conformation, and thus increase glucose entry into insulin-sensitive cells (Vincent, 2000, 2001). Chromium is thought to act with a small peptide usually referred to as low molecular weight chromium binding factor, but recently proposed to be named chromodulin (Sun et al., 2000; Vincent, 2000, 2001). The protein consists of glycine, cysteine, aspartate, and glutamate and binds with high affinity to 4 chromic ions (Vincent, 2000, 2001).

Chromium has resulted in a range of effects when fed to nonruminants or ruminants, but most studies have shown improved glucose tolerance (NRC, 1997; Hayirli et al., 2001; McNamara and Valdez, 2005). Organic sources of chromium, such as chromium propionate or chromium-methionine, have shown consistent positive effects on glucose use, feed intake, and milk production in dairy cattle compared with other chromium compounds (NRC, 1997; Hayirli et al., 2001; McNamara and Valdez, 2005). Chromium propionate has been approved for use in growing and lactating pigs based on many studies showing such an effect (Matthews et al., 2001, 2003; Shelton et al., 2003).

Chromium propionate fed to dairy cattle from $21 \mathrm{~d}$ prepartum to $35 \mathrm{~d}$ postpartum increased rates of lipogenesis and decreased net lipolysis in adipose tissue, and increased feed intake and milk production (McNamara and Valdez, 2005). Before continuing research into the effectiveness of chromium in lactating dairy cattle, it was thought valuable to test a possible mechanism of the biological activity of chromium propionate in ruminants by an intravenous glucose tolerance test (GTT) in growing dairy heifers. Therefore, the hypothesis of this experiment was that chromium propionate supplied orally in a dose-dependent fashion would improve glucose entry into insulin-sensitive tissues in an intravenous GTT.

\section{MATERIALS AND METHODS \\ Animals and Housing}

Twenty nonpregnant Holstein heifers ranging in age from 245 to $375 \mathrm{~d}$ [mean $304 \pm 40$ (SD)] and having BCS 
of 3 to 4 were selected for use. The trial commenced on February 6, 2004, and ended on June 27, 2004. Temperatures fluctuated between approximately 0 and $22^{\circ} \mathrm{C}$ during this time, with wind and rainfall within normal parameters for late winter and spring in the inland Pacific Northwest. Procedures followed the Guide for the Care and Use of Agricultural Animals in Agricultural Research and Teaching (FASS, 1999) and were approved by the University Animal Use and Care Committee. Animals were housed together in a covered free-stall barn partially enclosed on all sides, with approximately 20 animals in a pen, 2 waterers in every pen, with at least 1 feeding space per animal. The pen had lockups for individual animal feeding and handling. The concrete pad adjacent to the feeding trough was scraped once daily, and the free-stall area was cleaned and rebedded once weekly or more frequently as needed.

\section{Treatment Allotment and Administration}

The experiment was a replicated Latin square $(4 \times 4)$ with 5 replicates, designed to balance treatment crossover (described below). At 1 mo and 2 wk before the start of treatments, animals were sorted into pens, weighed, and body condition was scored. Animals were sorted by BW into groups of 5 and treatments were randomly allotted within each BW group. Body condition score was not sorted for or blocked, because variation between animals was small (mean of 3.4, minimum of 3, maximum of 4 , $\mathrm{SD}=0.37)$.

Animals were fed a TMR consisting of $45 \%$ oat and grass hay mix, $45 \%$ alfalfa hay, and $10 \%$ grain mix, offered daily at approximately $0800 \mathrm{~h}$. Individual feeding weights were not taken, but pen feed offerings and refusals were measured daily. Orts were removed from the feed trough each morning at $0700 \mathrm{~h}$, and individual buckets were installed to prevent neighbors from consuming treatment grain. The daily dose of chromium propionate was blended into a total of $0.25 \mathrm{~kg}$ of ground corn formulated to provide either $0,5,10$ or $15 \mathrm{mg} / \mathrm{d}$ chromium as chromium propionate $(\mathbf{C r P}$; KemTRACE Cr, Kemin Agri Foods North America Inc., Des Moines, IA). Animals were observed until the entire supplement was consumed, after which the individual buckets were removed, and the daily TMR was offered. There were only 6 refusals over the 1,120 supplement offerings. The animals were observed during the trial and for a period of $3 \mathrm{wk}$ post-trial for any acute abnormal indications or behavior.

\section{GTT}

On d 14 of each experimental period (between 1300 and $1600 \mathrm{~h}$ ), animals were brought to the veterinary treatment room approximately $100 \mathrm{~m}$ from the heifer barn. The area around the jugular vein was clipped, scrubbed, and anesthetized with $5 \mathrm{~mL}$ of lidocaine (2\%, no epinephrine; Abbott Laboratories, North Chicago, IL). A sterile, nonpyrogenic catheter (Abbocath-T, Abbott Laboratories) was inserted into the jugular vein and sutured to the skin. Catheters were flushed with sterile, nonpyrogenic saline with $10 \mathrm{IU}$ of heparin every $6 \mathrm{~h}$. The catheters were inserted alternately into the left or right side by period.

Animals were placed into a straw-bedded stall in the veterinary barn with access to TMR and water overnight. The next morning, feed was removed at $0600 \mathrm{~h}$. Water was available at all times. At $0700 \mathrm{~h}$, the GTT was conducted. Blood was sampled 15, 5, and 0 min before infusion. Glucose (dextrose) at $0.45 \mathrm{~g} / \mathrm{kg}$ of $\mathrm{BW}^{0.75}$ as a sterile, nonpyrogenic $50 \%$ (wt/vol) solution (range 35 to $45 \mathrm{~mL}$ ) was infused over the course of 1 to $2 \mathrm{~min}$, and the catheter was then flushed with $40 \mathrm{~mL}$ of saline. Further samples were taken at 5, 10, 20, 30, 45, 60, 90,120 , and 150 min after starting the infusion, and catheters were flushed before and after each sample. Samples were collected into tubes containing $\mathrm{NaF}$ to inhibit red blood cell glucose oxidation. The tubes were then immediately placed on ice and centrifuged within $1 \mathrm{~h}$ of collection.

\section{Glucose}

Glucose in serum was measured with an enzymatic kit supplied by Sigma (kit no. GAHK-20; Sigma, St. Louis, MO). Glucose is phosphorylated by adenosine triphosphate in a reaction catalyzed by hexokinase. Glucose-6 phosphate is then oxidized to 6-phospho-gluconate in the presence of NAD catalyzed by glucose- 6 phosphate dehydrogenase. During this oxidation an equimolar amount of $\mathrm{NAD}$ is reduced to $\mathrm{NADH}$ and the consequent increase in absorbance at $340 \mathrm{~nm}$ is directly proportional to glucose concentration. Blood was collected as described above and held on ice until centrifuged $(\sim 1 \mathrm{~h})$. The serum was collected, aliquoted, and frozen. Samples were thawed only once for each measurement. This assay was validated for use in cattle serum under the guidelines of the National Committee for Clinical Laboratory Standards (NCCLS, 2003, 2004).

\section{NEFA}

Nonesterified fatty acids were measured in serum enzymatically with the NEFA-C kit supplied by Wako Chemicals (Richmond, VA; as modified and validated to use less serum and to increase sensitivity (McNamara and Hillers, 1986; McNamara, 1988; Smith and McNamara, 1989). 
Table 1. Experimental treatment allotment in the Latin square, replicated 5 times (5 squares)

\begin{tabular}{lccccc}
\hline $\begin{array}{l}\text { Animal group/ } \\
\text { period }\end{array}$ & Period $0^{1}$ & Period 1 & Period 2 & Period 3 & Period $4^{1}$ \\
\hline Animal (row) 1 & 0 & 15 & 10 & 5 & 0 \\
Animal (row) 2 & 5 & 10 & 15 & 0 & 5 \\
Animal (row) 3 & 10 & 0 & 5 & 15 & 10 \\
Animal (row) 4 & 15 & 5 & 0 & 10 & 15 \\
\hline
\end{tabular}

\footnotetext{
${ }^{1}$ After measuring serum glucose after the original period 1 , after original feeding period 2 had already begun, but before the intravenous glucose tolerance test for period 2 was started, it was determined the glucose dose used in period 1 was too low. The glucose dose was recalculated and the study continued as originally designed, with period 0 repeated as the new period 4 with an adequate glucose challenge dose.
}

\section{Insulin}

Insulin was measured via RIA using kit DSL-1600 from Diagnostic Systems Laboratories (Webster, TX). Assays were conducted with all the samples from a complete period in each assay, in duplicate, with a standard in each assay (Nakagawa et al., 1973; Hwang et al., 1985; DSL-1600 Technical Bulletin).

\section{Statistical Design and Analysis}

The experimental design was a replicated $4 \times 4$ Latin square (Table 1 ). The experiment included one 2 -wk pretreatment period, four 2-wk treatment periods, and one 2 -wk flushing period between periods. The design was allotted to balance for carryover affects, and each treatment was followed by another treatment only once (Steel and Torrie, 1980). Treatments were randomly assigned to period for each animal. The final model used for the GTT data with the exception of the insulin variables was

$$
\mathrm{y}=\mu+\mathrm{B}+\mathrm{R}_{\mathrm{i}}+\mathrm{C}_{\mathrm{j}}+\mathrm{T}_{\mathrm{k}}+\mathrm{S}_{\mathrm{l}}+\text { error }_{\mathrm{ijk}}
$$

where $\mu$ is the mean, B is the effect of covariable (basal concentration of glucose, insulin, or NEFA; average of 3 preinfusion points), $\mathrm{R}$ the effect of row (animal), $\mathrm{C}$ the effect of column (period), $\mathrm{T}$ the effect of treatment, and $\mathrm{S}$ the effect of square (replicate). Animal within square and the interaction terms were in the original model, however were not significant and were dropped from the final model. For insulin, there was a period $\times$ treatment interaction for all time points and measures and that term was left in the model. All effects except animal within square were considered fixed.

After completion of the first feeding period and before the GTT of the second period, analysis of the glucose samples indicated that the planned glucose challenge dose $\left(0.15 \mathrm{~g} / \mathrm{kg}\right.$ of $\left.\mathrm{BW}^{0.75}\right)$ was inadequate to properly test the hypothesis. Because a similar GTT had not been reported previously for heifers of this age, this original dose was designed to be similar to that for older animals (Hayirli et al., 2001), but proved to be too low. By this time, the subsequent feeding period had already begun, and there was no overriding reason to stop the experiment and reassign treatments to begin again. Therefore, from this point on, the GTT dose was increased to that reported $\left(0.45 \mathrm{~g} / \mathrm{kg}\right.$ of $\left.\mathrm{BW}^{0.75}\right)$ based on work with calves (DePew et al., 1998; Bunting et al., 2000). Thus, the original first period was not included in the data set. The same treatments originally in the first period were reassigned to a fifth period and the experiment completed. Thus, the final design was a complete Latin square, with each period receiving each treatment once.

The variables analyzed for the GTT data for glucose and insulin included basal (mean of $-15,-5$, and 0 time samples), peak, and minimum (nadir) concentration, clearance rate (CR), area under the curve (AUC; trapezoidal method), half-life $\left(\mathbf{t}_{\mathbf{1} / 2}\right)$, and time to return to basal level (T) as actual values. Nonesterified fatty acids are reported as individual values and analyzed at each time point and as basal (average preinfusion) and response (average postinfusion value minus preinfusion). Because of the expected triphasic response in NEFA (initial increase due to handling, decrease as glucose and insulin increase, and then increase to basal) and lack of specific treatment effects, no further attempt was made to fit statistical models to these data.

\section{RESULTS AND DISCUSSION}

\section{$B W S$ and $B C S$}

Growth rates were typical for Holstein heifers fed a diet containing 12 to $14 \% \mathrm{CP}$ (Table 2). There were no effects of chromium propionate on BW, which was expected in this short-term experiment. Similarly, BCS (5point scale) were not affected by treatment (Table 2 ).

\section{Glucose Response}

Basal glucose tended to be increased by 10 and $15 \mathrm{mg} /$ d chromium (Table 3, Figure 1). Glucose concentrations are in the same range as has been reported for lactating cows and younger calves (Bunting et al., 2000; McNa- 
Table 2. Body weights and condition scores of Holstein heifers consuming chromium propionate

\begin{tabular}{|c|c|c|c|c|c|}
\hline \multirow[b]{2}{*}{ Treatment $^{1}$} & \multicolumn{5}{|c|}{ Period } \\
\hline & Initial & 1 & 2 & 3 & 4 \\
\hline \multicolumn{6}{|l|}{$\mathrm{BW}, \mathrm{kg}$} \\
\hline $0 \mathrm{mg}$ & 168.7 & 174.0 & 175.4 & 173.6 & 179.0 \\
\hline $5 \mathrm{mg}$ & 163.9 & 170.6 & 171.6 & 178.8 & 179.8 \\
\hline $10 \mathrm{mg}$ & 164.8 & 172.8 & 175.6 & 1776.0 & 179.4 \\
\hline $15 \mathrm{mg}$ & 168.6 & 169.4 & 173.2 & 177.6 & 182.6 \\
\hline SEM & 1.7 & 1.77 & 1.61 & 1.63 & 1.77 \\
\hline \multicolumn{6}{|c|}{ Change in BW by period, $\mathrm{kg}$} \\
\hline $0 \mathrm{mg}$ & & 10.3 & 4.8 & 0.4 & 0.2 \\
\hline $5 \mathrm{mg}$ & & 6.7 & -2.4 & 3.8 & 6.2 \\
\hline $10 \mathrm{mg}$ & & 8.0 & 6.2 & 3.6 & 1.8 \\
\hline $15 \mathrm{mg}$ & & 0.8 & 0.4 & 6.0 & 6.6 \\
\hline SEM & & 1.61 & 1.43 & 1.10 & 1.30 \\
\hline \multicolumn{6}{|c|}{ BCS by period } \\
\hline $0 \mathrm{mg}$ & 3.28 & 3.6 & 3.5 & 3.8 & 3.9 \\
\hline $5 \mathrm{mg}$ & & 3.1 & 4.0 & 3.8 & 3.8 \\
\hline $10 \mathrm{mg}$ & & 3.6 & 4.1 & 3.6 & 3.9 \\
\hline $15 \mathrm{mg}$ & & 3.2 & 3.9 & 3.9 & 3.5 \\
\hline SEM & & 0.09 & 0.09 & 0.09 & 0.11 \\
\hline
\end{tabular}

${ }^{1}$ Treatments were control ( $0 \mathrm{mg}$ of chromium), or 5,10 , or $15 \mathrm{mg} / \mathrm{d}$ chromium supplied by chromium propionate. There were no statistical differences at $P<0.05$ in any of these measures.

mara and Valdez, 2005). Glucose clearance during the GTT was increased as noted by all measures (CR, T, $\mathrm{t}_{1 / 2}$, and AUC; Table 3, Figure 1) compared with the control. The reduction in AUC (i.e., faster clearance) was $36 \%$ over all 3 treatments $(P=0.097)$. There is often wide variation in glucose flux among animals, but this amount of change in glucose clearance is impressive compared with other studies in cattle, in which a 10 to $20 \%$ change is biologically significant (Bunting et al., 2000; Hayirli et al., 2001). This result is consistent with a faster rate of uptake of glucose by the main insulinsensitive tissues, skeletal muscle and adipose.

Table 3. Least squares means for plasma glucose concentration parameters during intravenous glucose tolerance test (GTT), including glucose half time $\left(t_{1 / 2}\right)$, clearance rate $(\mathrm{CR})$, time to nadir glucose $(\mathrm{T})$, and glucose area under the curve (AUC) ${ }^{1}$

\begin{tabular}{|c|c|c|c|c|c|}
\hline \multirow[b]{2}{*}{ Item } & \multirow[b]{2}{*}{$\mathrm{n}$} & \multicolumn{4}{|c|}{ Glucose concentration parameter } \\
\hline & & $\begin{array}{l}\mathrm{t}_{1 / 2}, \\
\mathrm{~min}\end{array}$ & $\mathrm{CR}, \% / \mathrm{min}$ & $\mathrm{T}, \mathrm{min}$ & $\begin{array}{c}\mathrm{AUC} \\
\mathrm{mg} / \mathrm{dL} \cdot \mathrm{min}\end{array}$ \\
\hline \multicolumn{2}{|l|}{ Period } & $\longrightarrow$ & \multicolumn{2}{|c|}{ - By period (across treatments } & \\
\hline 1 & 17 & 112.1 & 0.723 & 45.6 & 479 \\
\hline 2 & 18 & 95.3 & 0.762 & 45.0 & 553 \\
\hline 3 & 17 & 121.2 & 0.601 & 46.8 & 701 \\
\hline 4 & 16 & 112.0 & 0.650 & 46.3 & 550 \\
\hline SEM & & 3.7 & 0.029 & 1.25 & 71.8 \\
\hline$P($ period $)$ & & 0.12 & 0.20 & 0.16 & 0.68 \\
\hline \multicolumn{2}{|l|}{ Treatment } & & \multicolumn{2}{|c|}{ By treatment (across periods } & \\
\hline $0 \mathrm{mg}$ & 17 & 119.7 & 0.598 & 46.9 & 741 \\
\hline $5 \mathrm{mg}$ & 15 & 113.6 & 0.693 & 46.0 & 587 \\
\hline $10 \mathrm{mg}$ & 18 & 101.7 & 0.746 & 45.2 & 450 \\
\hline $15 \mathrm{mg}$ & 18 & 105.6 & 0.697 & 45.7 & 504 \\
\hline SEM & & 6.6 & 0.051 & 1.25 & 71.8 \\
\hline$P$ (Treatment) & & 0.26 & 0.25 & 0.21 & 0.44 \\
\hline$P$ (Control vs. all Cr doses $)$ & & 0.11 & 0.06 & 0.06 & 0.14 \\
\hline$P($ Control vs. $5 \mathrm{mg})$ & & 0.53 & 0.21 & 0.26 & 0.41 \\
\hline$P($ Control vs. $10 \mathrm{mg})$ & & 0.07 & 0.05 & 0.04 & 0.13 \\
\hline$P($ Control vs. $15 \mathrm{mg})$ & & 0.14 & 0.18 & 0.15 & 0.20 \\
\hline Linear dose & & 0.18 & 0.06 & 0.06 & 0.17 \\
\hline Quadratic dose & & 0.40 & 0.15 & 0.19 & 0.33 \\
\hline
\end{tabular}

${ }^{1}$ Treatments were control ( $0 \mathrm{mg}$ of chromium), or 5,10 , or $15 \mathrm{mg} / \mathrm{d}$ chromium supplied by chromium propionate. 

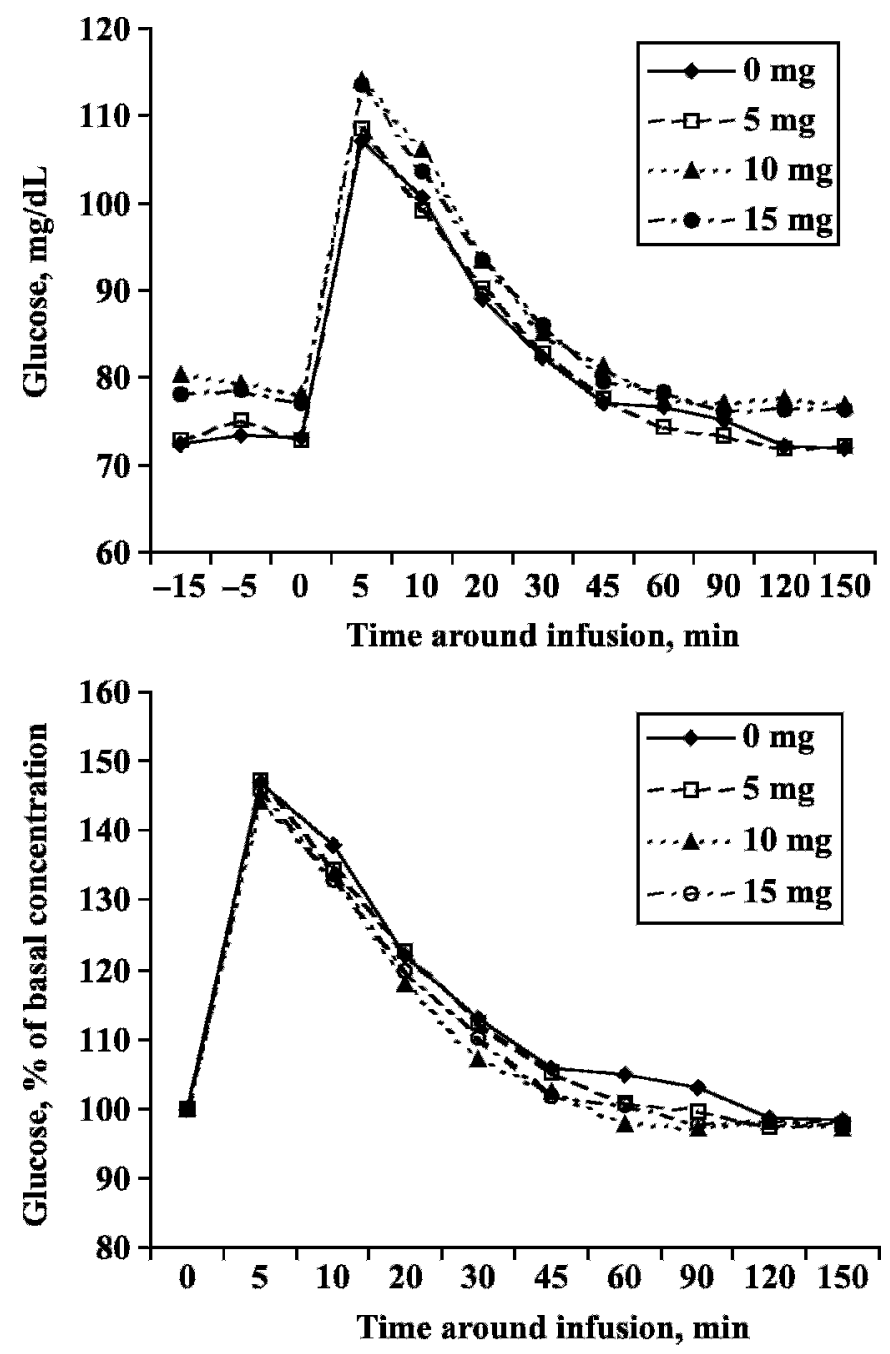

Figure 1. Effect of chromium propionate on glucose clearance in an intravenous glucose tolerance test in Holstein heifers consuming chromium propionate. Top: absolute glucose concentration $(\mathrm{mg} / \mathrm{dL}$ of glucose); bottom: glucose as percentage of basal concentration. Average SEM for each time point was $1.61 \mathrm{mg} / \mathrm{dL}$, or $2.0 \%$ of the mean.

Current knowledge supports the hypothesis that the insulin-sensitive glucose uptake mechanism is enhanced by chromium propionate. The most likely mechanism is through chromium binding with a low molecular weight peptide, enhancing insulin action after insulin binds to its receptor and resulting in increased translocation of glucose transporters, most likely GLUT4, to the cell membrane (Shepherd and Kahn, 1999; Cefalu et al., 2002). The glucose CR and AUC are also shown in figure form (Figure 2) demonstrating the coordinated effect: an increase of $\mathrm{CR}$ and concomitant reduction of AUC.

\section{Insulin Response}

Insulin concentration responded to an infusion of glucose by increasing quickly to a peak about 3 to 4 times

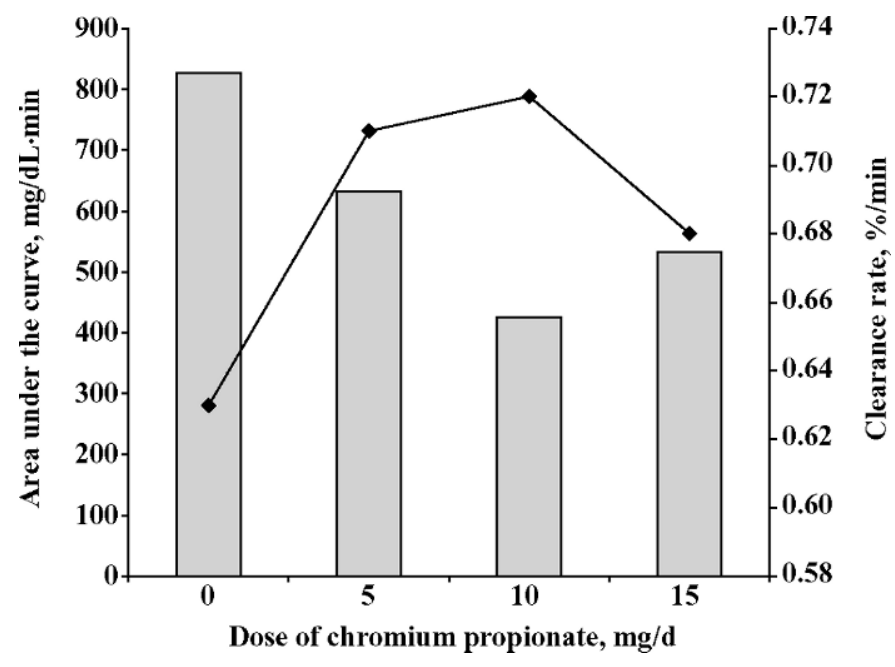

Figure 2. Glucose clearance rate and area under the curve in an intravenous glucose tolerance test in Holstein heifers consuming chromium propionate. Bar graphs represent area under the curve $(\mathrm{mg} / \mathrm{dL} \cdot \mathrm{min})$; line is clearance rate $(\% / \mathrm{min})$. Average SEM for area under the curve was $70.2 \mathrm{mg} / \mathrm{dL} \cdot \mathrm{min}$ or $1.2 \%$ of the mean; average SEM for clearance rate was $0.0277 \% / \mathrm{min}$ or $4 \%$ of the mean.

basal concentrations (Table 4, Figure 3). There were no statistically significant differences due to treatment in any of the insulin variables. The similarity in insulin clearance combined with the improved glucose clearance indicates an improved sensitivity to insulin in the tissues. However, examination and analysis of the insulin concentrations for the control group in period 4 as compared with the first 3 periods revealed a period $\times$ treatment interaction $(P<0.05)$ such that insulin concentrations were lower in control animals in period $4(P<0.05$ for all time points in the GTT when the effect of period was tested within the control treatment alone).

A more rapid glucose disappearance with no difference in insulin clearance in an in vitro GTT indicates a greater sensitivity to insulin at the tissue level. In the fourth period, insulin concentrations for control animals were less than those for controls in the first 3 periods. Animals receiving the control treatment in period 4 had been receiving 3 consecutive doses of chromium propionate in the last $6 \mathrm{wk}$. We explicitly designed the experiment to balance for potential carryover, as the literature database would suggest this as a possibility (NRC, 1997; McNamara and Valdez, 2005). If in fact this were a real effect, it would be consistent with a potential long-term effect of supplementary chromium on insulin sensitivity. Whether this is a real effect awaits confirmation, but mechanisms may include increasing chromium stores or increasing pancreatic sensitivity.

\section{NEFA Response}

The response of NEFA to a glucose challenge was as expected (Figure 4 and Table 5), with a slight increase 
Table 4. Insulin clearance in Holstein heifers consuming chromium propionate ${ }^{1}$

\begin{tabular}{|c|c|c|c|c|c|c|}
\hline & \multirow[b]{2}{*}{$\mathrm{n}$} & \multicolumn{5}{|c|}{ Insulin concentration parameter ${ }^{2}$} \\
\hline & & $\begin{array}{l}\text { Basal, } \\
\mathrm{mg} / \mathrm{dL}\end{array}$ & $\begin{array}{l}\mathrm{t}_{1 / 2} \\
\mathrm{~min}\end{array}$ & $\begin{array}{c}\mathrm{CR}, \\
\% / \mathrm{min}\end{array}$ & $\mathrm{T}, \min$ & $\begin{array}{c}\mathrm{AUC} \\
\mathrm{mg} / \mathrm{dL} \cdot \mathrm{min}\end{array}$ \\
\hline \multicolumn{2}{|l|}{ Period } & \multicolumn{5}{|c|}{$\longrightarrow$ By period (across treatments) } \\
\hline 1 & 17 & 6.37 & 27.5 & 2.750 & 26.91 & 214 \\
\hline 2 & 18 & 5.82 & 28.3 & 2.750 & 27.88 & 212 \\
\hline 3 & 17 & 9.22 & 26.6 & 2.691 & 28.91 & 353 \\
\hline 4 & 16 & 8.27 & 33.5 & 2.413 & 31.19 & 331 \\
\hline SEM & & 0.318 & 1.46 & 0.090 & 0.87 & 22.7 \\
\hline$P($ period $)$ & & 0.001 & 0.057 & 0.044 & 0.069 & 0.12 \\
\hline \multicolumn{2}{|l|}{ Treatment } & \multicolumn{5}{|c|}{ - By treatment (across periods) } \\
\hline $0 \mathrm{mg}$ & 17 & 7.95 & 28.74 & 2.752 & 26.91 & 243 \\
\hline $5 \mathrm{mg}$ & 15 & 6.71 & 27.99 & 2.610 & 27.88 & 305 \\
\hline $10 \mathrm{mg}$ & 18 & 7.42 & 27.73 & 2.724 & 28.91 & 315 \\
\hline $15 \mathrm{mg}$ & 18 & 7.66 & 31.36 & 2.517 & 31.19 & 249 \\
\hline SEM & & 0.318 & 1.32 & 0.082 & 0.84 & 22.7 \\
\hline Treatment & & 0.57 & 0.74 & 0.71 & 0.44 & 0.59 \\
\hline Control vs. all $\mathrm{Cr}$ doses & & 0.35 & 0.92 & 0.48 & 0.52 & 0.36 \\
\hline Control vs. $5 \mathrm{mg}$ & & 0.18 & 0.85 & 0.56 & 0.86 & 0.35 \\
\hline Control vs. $10 \mathrm{mg}$ & & 0.55 & 0.79 & 0.90 & 0.98 & 0.27 \\
\hline Control vs. $15 \mathrm{mg}$ & & 0.74 & 0.46 & 0.29 & 0.16 & 0.92 \\
\hline Linear dose & & 0.26 & 0.54 & 0.98 & 0.67 & 0.17 \\
\hline Quadratic dose & & 0.25 & 0.41 & 0.82 & 0.42 & 0.17 \\
\hline
\end{tabular}

${ }^{1}$ Treatments were control ( $0 \mathrm{mg}$ of chromium), or 5,10 , or $15 \mathrm{mg} / \mathrm{d}$ chromium supplied by chromium propionate.

${ }^{2}$ Parameters: $t_{1 / 2}=$ glucose half-life $; C R=$ clearance rate; $\mathrm{T}=$ time to nadir glucose; $\mathrm{AUC}=$ glucose area under the curve.

upon initiation of handling animals due to stress followed by a reduction in NEFA as glucose entry increased after infusion, and eventually ending with an increase of NEFA to previous concentrations as glucose decreased. There were no measured effects of treatment on rates of NEFA fluctuation. However, there was a trend for treatment to decrease $(P=0.08)$ average NEFA concentration (Table 5).

Historical work with various supplemental chromium forms in nonruminants has consistently shown an improvement in glucose tolerance and a reduction in NEFA concentrations (NRC, 1997; Matthews et al., 2001, 2003). In ruminants, the data have been less consistent, with various studies showing small improvements in glucose clearance in young animals, and others showing little effect (NRC, 1997; Depew et al., 1998; Bunting et al., 2000). Recent work with organic compounds such as chromium methionine or chromium propionate, however, has given more consistent increases in glucose clearance in late pregnant or lactating animals (Hayirli et al., 2001; McNamara and Valdez, 2005). Given the great range of rates of glucose supplying and utilizing reactions during late pregnancy and early lactation (McNamara, 2005), it is surprising that one could find such an effect. Yet the indications are that the increased effectiveness of organic chromium compounds may be improving glucose uptake in insulin sensitive tissues in ruminants.

Chromium is involved in the uptake of glucose by insulin-sensitive cells through its action with chromodulin, which is the name currently suggested for a low molecular weight chromium binding protein (Sun et al., 2000). Chromodulin is stored in its metal-free apo-form inside insulin dependent cells. In response to insulin, chromium is mobilized from the blood and transported into these cells. Movement of chromic ions into the cell results in the generation of holochromodulin, which binds to the insulin-activated form of the insulin receptor, which amplifies the tyrosine kinase activity of the receptor and increases the magnitude and duration of the signaling cascade (Jacquamet et al., 2003). This results in greater sensitivity to insulin and more transport of glucose into insulin-sensitive tissues such as adipose and muscle and explains the improved glucose tolerance in animals receiving supplemental chromium.

Work to date in dairy cattle has not attempted to separate effects of chromium action on muscle or adipose tissue. We have demonstrated (McNamara and Valdez, 2005) that chromium propionate fed to dairy cattle from $21 \mathrm{~d}$ prepartum to $35 \mathrm{~d}$ postpartum gave a large increase (several fold) in adipose tissue lipogenesis measured in in vitro incubations. Lipolysis rates were decreased on 


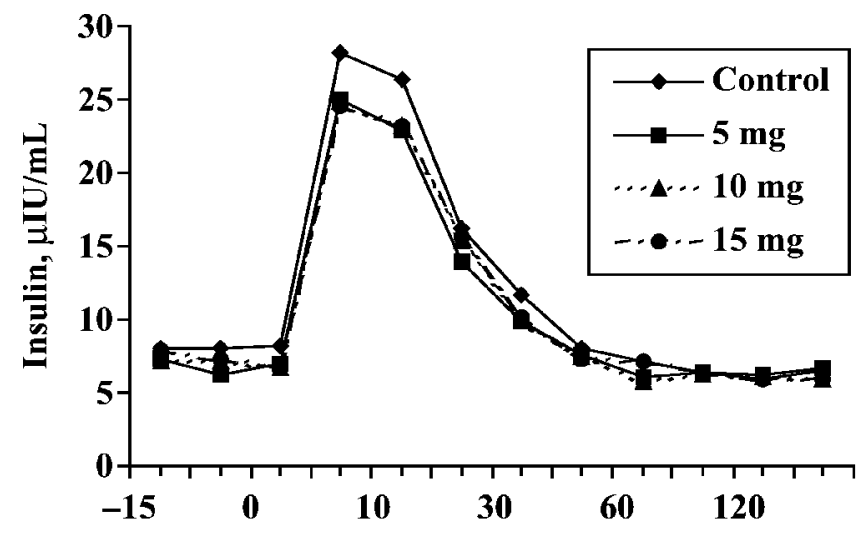

Time around infusion, min

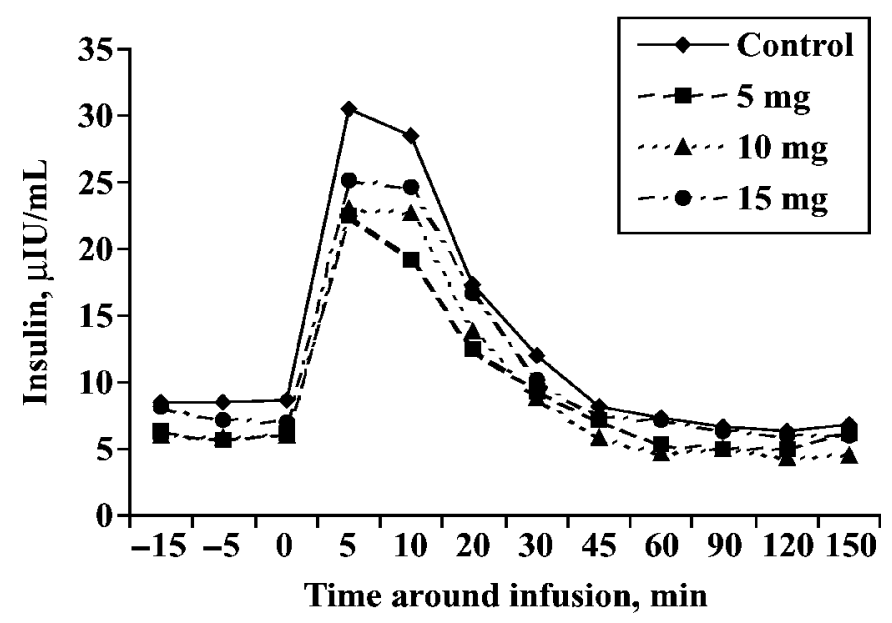

Figure 3. Insulin response to an intravenous glucose tolerance test in Holstein heifers consuming chromium propionate. Top: overall periods; bottom: insulin in periods 1 through 3 only. Average SEM for each time point was $1.64 \mu \mathrm{IU} / \mathrm{mL}$, or $17 \%$ of the mean.

the order of 10 to $15 \%$, together resulting in a reduction of net FFA release at the whole-body level of approximately $200 \mathrm{~g} / \mathrm{d}$ (McNamara, 2005). This is a massive response of metabolic rates, especially given the rapid and extreme adaptations in these pathways in dairy animals ( $\mathrm{McNa}-$ mara and Hillers, 1986; McNamara, 2005). Chromium also increased feed intake and milk production in those cows (McNamara and Valdez, 2005). Although the question of "which came first" remains, the theory that chromium enhances glucose uptake in adipose tissue, therefore reducing lipolysis, and allowing a faster rate of feed intake and a subsequent increase in milk production, is a plausible one. Further work could help confirm or refute this theory and mechanisms of action in adipose tissue and muscle.

\section{CONCLUSIONS}

Oral supplementation of chromium improved utilization of glucose in growing heifers in a dose-response

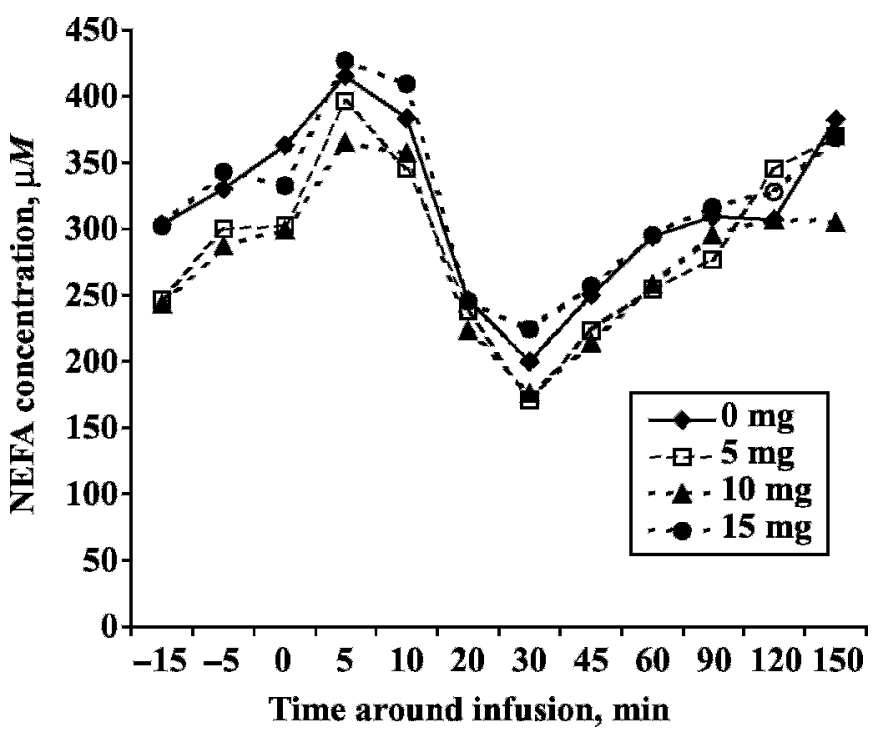

Figure 4. Nonesterified fatty acid response to an intravenous glucose tolerance test in Holstein heifers consuming chromium propionate.

fashion from 5 to $15 \mathrm{mg} / \mathrm{d}$. All measures of glucose clearance after a standard intravenous GTT indicated faster clearance and greater irreversible loss (area under the curve postinfusion) of glucose from blood into tissues. The 2 major insulin-sensitive organs are muscle and fat. In heifers of this age, it would be valid to conclude that muscle was the major recipient of the glucose load, although it is also consistent with present knowledge that glucose entry into adipocytes also increased. A faster rate of glucose utilization ( $\mathrm{t}_{1 / 2}$; time to nadir) and greater AUC, coupled with unchanged or lowered insulin, is interpreted as improved peripheral response to insulin in treated animals.

Table 5. Nonesterified fatty acids in Holstein heifers consuming chromium propionate $^{1}$

\begin{tabular}{lcc}
\hline & $\begin{array}{c}\text { Basal NEFA, } \\
\mu M\end{array}$ & $\begin{array}{c}\text { Mean response, } \\
\mu M\end{array}$ \\
\hline Treatment & & \\
$0 \mathrm{mg}$ & 332.1 & -21.6 \\
$5 \mathrm{mg}$ & 282.9 & 4.5 \\
$10 \mathrm{mg}$ & 275.1 & -9.1 \\
$15 \mathrm{mg}$ & 323.5 & -3.3 \\
$\mathrm{SEM}$ & 19.0 & 8.20 \\
& $P$-value & \\
Treatment & 0.08 & \\
Control vs. all Cr doses & 0.1 & \\
Control vs. $5 \mathrm{mg}$ & 0.11 & \\
Control vs. $10 \mathrm{mg}$ & 0.06 & \\
Control vs. $15 \mathrm{mg}$ & $\mathrm{NS}$ & \\
\hline
\end{tabular}

${ }^{1}$ Treatments were control ( $0 \mathrm{mg}$ of chromium), or 5,10 , or $15 \mathrm{mg} /$ d chromium supplied by chromium propionate. 


\section{ACKNOWLEDGMENTS}

We would like to thank Jan Vierck, Mary Kate Biddle, Erin Healy, Jennifer Gerber, Tracy Hanger, Garth Millard, John Swain, and Arlene Lamptey for their excellent technical assistance.

\section{REFERENCES}

Anderson, R. A. 1987. Chromium. Pages 225-244 in Trace Elements in Human and Animal Nutrition. Vol. 1. 5th ed. W. Mertz, ed. Academic Press Inc., New York, NY.

Bunting, L. D., T. A. Tarifa, B. T. Crochet, J. M. Fernandez, C. L. Depew, and J. C. Lovejoy. 2000. Effects of dietary inclusion of chromium propionate and calcium propionate on glucose disposal and gastrointestinal development in dairy calves. J. Dairy Sci. 83:2491-2498.

Cefalu, W. T., Z. Q. Wang, X. H. Zhang, L. C. Baldor, and J. C. Russell. 2002. Oral chromium picolinate improves carbohydrate and lipid metabolism and enhances skeletal muscle Glut-4 translocation in obese, hyperinsulinemic (JCR-LA corpulent) rats. J. Nutr. 132:1107-1114.

DePew, C. L., L. D. Bunting, J. M. Fernandez, D. L. Thompson, Jr., and R. W. Adkinson. 1998. Performance and metabolic responses of young dairy calves fed diets supplement with chromium tripicolinate. J. Dairy Sci. 81:2916-2923.

FASS. 1999. Guide for the Care and Use of Agricultural Animals in Agricultural Research and Teaching. FASS (Federation of Animal Science Societies), Savoy, IL.

Hayirli, A., D. R. Bremmer, S. J. Bertics, M. T. Socha, and R. R. Grummer. 2001. Effect of chromium supplementation on production and metabolic parameters in periparturient dairy cows. J. Dairy Sci. 84:1218-1230.

Hwang, D. L., G. Barsehgian, and A. Lev-Ran. 1985. Determination of free-insulin in antibody containing sera: Comparison of polyethylene glycol and Staphylococcus aureus cells. Horm. Metab. Res. 17:595-597.

Jacquamet, L., Y. Sun, J. Hatfeild, W. Gu, S. Cramer, M. Crowder, G. Lorigan, J. Vincent, and J. Latour. 2003. Characterization of chromodulin by x-ray absorption and electron paramagnetic resonance spectroscopies and magnetic susceptibility measurements. J. Am. Chem. Soc. 125:774-780.

Matthews, J. O., A. D. Higbie, L. L. Southern, D. F. Coombs, T. D. Bidner, and R. L. Odgaard. 2003. Effect of chromium propionate and metabolizable energy on growth, carcass traits, and pork quality of growing-finishing pigs. J. Anim. Sci. 81:191-196.

Matthews, J. O., L. L. Southern, J. M. Fernandez, J. E. Pontif, T. D. Bidner, and R. D. Odgaard. 2001. Effect of chromium picolinate and chromium propionate on glucose insulin kinetics of growing barrows and on growth and carcass traits of growing-finishing barrows. J. Anim. Sci. 79:2172-2178.
McNamara, J. P. 1988. Regulation of bovine adipose tissue metabolism during lactation 4. Dose-responsiveness to epinephrine as altered by stage of lactation. J. Dairy Sci. 71:643-649.

McNamara, J. P. 2005. Chapter 6: Research, Improvement and application of mechanistic, biochemical, dynamic models: From genetics to kinetics. Pages 87-110 in Mathematical modeling in nutrition and Toxicology. Proc. 8th Int. Conf. Math. Modeling Nutr. Health Sci. Mathematical Biology Press, Athens, GA.

McNamara, J. P., and J. K. Hillers. 1986. Regulation of bovine adipose tissue metabolism during lactation 2. Lipolysis response to milk production and energy intake. J. Dairy Sci. 69:3042-3050.

McNamara, J. P., and F. Valdez. 2005. Adipose tissue metabolism and production responses to calcium propionate and chromium propionate. J. Dairy Sci. 88:2498-2507.

Nakagawa, S., H. Nakayama, T. Sasaki, K. Yoshino, Y. Y. Yu, K. Shinozaki, S. Aoki, and K. Mashimo. 1973. A simple method for the determination of serum free insulin levels in insulin-treated patients. Diabetes 22:590-600.

NCCLS. 2003. NCCLS publication EP6-A, Vol. 23, No. 16. Evaluation of the linearity of quantitative measurement procedures: A statistical approach. Approved guideline. Clinical Laboratory Standards Institute (formerly NCCLS), Wayne, PA.

NCCLS. 2004. NCCLS publication EP5-A, Vol. 24, No. 25. Evaluation of precision performance of quantitative measurement methods. Approved guideline, 2nd ed. Clinical Laboratory Standards Institute (formerly NCCLS), Wayne, PA.

NRC. 1997. The Role of Chromium in Animal Nutrition. National Academy Press, Washington, DC.

Phillips, G. J., T. L. Citron, J. S. Sage, K. A. Cummins, M. J. Cecava, and J. P. McNamara. 2003. Adaptations in body muscle and fat in transition dairy cattle fed differing amounts of protein and methionine hydroxy analog. J. Dairy Sci. 86:3634-3647.

Shelton, J. L., R. L. Payne, S. L. Johnston, T. D. Bidner, L. L. Southern, R. L. Odgaard, and T. G. Page. 2003. Effect of chromium propionate on growth, carcass traits, and pork quality of growing-finishing pigs. J. Anim. Sci. 81:2515-2524.

Shepherd, P. R., and B. B. Kahn. 1999. Glucose transporters and insulin action: Implications for insulin resistance and diabetes mellitus. N. Engl. J. Med. 341:248-257.

Smith, D. J., and J. P. McNamara. 1989. Lipolytic response of bovine adipose tissue to alpha and beta-adrenergic agonists 30 days preand 120 days postpartum. Gen. Pharmacol. 20:369-374.

Steel, R. G. D., and J. H. Torrie. 1980. Principles and procedures of statistics. McGraw-Hill, New York, NY.

Sun, Y., J. Ramirez, S. A. Woski, and J. B. Vincent. 2000. The binding of chromium to low-molecular-weight chromium-binding-substance (LMWCr) and the transfer of chromium from chromium picolinate to LMWCr. J. Biol. Inorg. Chem. 5:129-136.

Vincent, J. B. 2000. The biochemistry of chromium. J. Nutr. 130:715-718.

Vincent, J. B. 2001. The bioinorganic chemistry of chromium(III). Polyhedron 20:1-26. 